\title{
STAGED APPROACH TO TREATMENT OF COMBINED HAMARTOMA OF THE RETINA AND RETINAL PIGMENT EPITHELIUM
}

Takhchidi KhP, Takhchidi NKh, Kasminina TA, Tebina EP 凶

Pirogov Russian National Medical Research University, Moscow, Russia

Combined hamartoma of the retina and retinal pigment epithelium (RPE) is a rare congenital benign lesion. It is most often detected in young adults and adolescents. The disorder is mostly asymptomatic, however, in $24 \%$ of patients the loss of visual function results from complications, such as epiretinal fibrosis associated with tractional distortion of the fovea, hemophthalmos, choroidal neovascularization, exudative retinal detachment, macular edema, and combined tractional/rhegmatogenous retinal detachment. Currently, there is no consensus on the combined hamartoma complications management. The reported clinical case demonstrates the feasibility of staged approach to treatment of combined hamartoma of the retina and RPE complicated by epiretinal fibrosis and partial hemophthalmos using the advanced diagnosis (optical coherence tomography) and treatment methods.

Keywords: hamartoma, retinal pigment epithelium, retina, laser photocoagulation, angiogenesis inhibitor

Author contribution: Takhchidi KhP — study concept and design, manuscript editing; Takhchidi NKh — literature analysis; Tebina EP — data acquisition and processing, manuscript writing; Kasminina TA — laser treatment.

Compliance with ethical standards: the patient submitted informed consent to staged surgery and personal data processing.

$\triangle$ Correspondence should be addressed: Ekaterina P. Tebina

Volokolamskoe shosse, 30, str. 2, Moscow, 123182; ekaterinatebina@mail.ru

Received: 07.09.2020 Accepted: 03.10.2020 Published online: 12.10.2020

DOI: $10.24075 /$ brsmu.2020.060

\section{ПОЭТАПНЫЙ ПОДХОД В ЛЕЧЕНИИ КОМБИНИРОВАННОЙ ГАМАРТОМЫ СЕТЧАТКИ И РЕТИНАЛЬНОГО ПИГМЕНТНОГО ЭПИТЕЛИЯ}

\author{
Х. П. Тахчиди, Н. Х. Тахчиди, Т. А. Касмынина, Е. П. Тебина \\ Российский национальный исследовательский медицинский университет имени Н. И. Пирогова, Москва, Россия
}

\begin{abstract}
Комбинированная гамартома пигментного эпителия и сетчатки - редкое врожденное доброкачественное новообразование. Наиболее часто ее выявляют у молодых людей и подростков. В большинстве случаев заболевание протекает бессимптомно, однако в 24\% снижение зрительных функций обусловлено развитием осложнений: эпиретинального фиброза, сопровождающегося тракционным искажением фовеа, гемостальмом, хориоидальной неоваскуляризацией, экссудативной отслойкой сетчатки, макулярным отеком, тракционной/регматогенной отслойкой сетчатки. В настоящее время не существует единого мнения в лечении осложнений, вызванных комбинированной гамартомой. Данный клинический случай демонстрирует возможность поэтапного лечения комбинированной гамартомы сетчатки и ретинального пигментного эпителия, осложненного эпиретинальным фиброзом и частичным гемофтальмом, с использованием современных методов диагностики (оптическая когерентная томография) и лечения.
\end{abstract}

Ключевые слова: гамартома, ретинальный пигментный эпителий, сетчатка, лазерная коагуляция, ингибитор неоангиогенеза

Вклад авторов: Х. П. Тахчиди — концепция и дизайн исследования, редактирование текста; Н. Х. Тахчиди — анализ литературных данных; Е. П. Тебина сбор и обработка материала, написание текста; Т. А. Касмынина - лазерное лечение пациента.

Соблюдение этических стандартов: от пациента получено добровольное информированное согласие на поэтапное оперативное лечение и обработку персональных данных.

$\triangle$ Для корреспонденции: Екатерина Павловна Тебина

Волоколамское шоссе, д. 30, корп. 2, г. Москва, 123182; ekaterinatebina@mail.ru

Статья получена: 07.09.2020 Статья принята к печати: 03.10.2020 Опубликована онлайн: 12.10.2020

DOI: $10.24075 /$ vrgmu.2020.060

Combined hamartoma of the retina and retinal pigment epithelium (RPE) is an uncommon benign lesion. This congenital lesion is most often found at an early age. The tumor was first described by Gass in 1973 [1].

Hamartoma is usually associated with tuberous sclerosis (Bourneville disease), and is less frequently detected in patients with neurofibromatosis type II (to a lesser extent in patients with neurofibromatosis type I), Gorlin syndrome, juvenile nasopharyngeal angiofibroma. However, solitary tumors of the described type may occur sporadically in healthy people [2-4]

The total disorganization of the inner retinal layers associated with glial cell and pigment epithelial cell proliferation is observed in histological sections [2]. Gass distinguished the following four types of combined hamartoma based on the tumor location and clinical manifestations: papillary and juxta-papillary (56-76\%), macular (17-38\%) and peripheral (5-7\%) [1, 4].

Lesion is usually detected through routine fundus examination or when handling patients complaining of decreased visual acuity, strabismus, leukocoria. The loss of visual function directly depends on the degree of macular and optic nerve involvement. Combined hamartomas are usually unilateral, however, there are several documented cases of bilateral lesions [4].

Juxta-papillary, papillary or macular hamartomas are visualized by ophtalmoscopy as protruding lesions with blurred margins. The tumor with nonuniform pigmentation is light or dark grey, and covered with semi-translucent shiny membrane. The abnormally tortuous retinal blood vessels are frequently noted, and in a number of patients, exudative retinal detachment, microhemorrhages and hard exudates are detected [4]. Peripheral combined hamartomas are associated with significant preretinal blood vessels malformations and retinal thickening, and the tumor margins are poorly distinguishable.

Currently, optical coherence tomography (OCT) makes it possible to image the morphometric features of combined hamartoma: epiretinal membrane, minor vertical vitreoretinal 
traction (mini peaks), major vertical vitreoretinal traction with folding of inner retinal layers (maxi peaks), distortion of the outer plexiform layer (saw tooth appearance or "omega" sign) [5-8].

In $24 \%$ of patients, the loss of visual function results from complications of the disease: epiretinal fibrosis associated with vitreomacular traction syndrome, hemophthalmos, choroidal neovascularization, exudative retinal detachment, macular edema, combined tractional and rhegmatogenous retinal detachment [2].

To date, there is no consensus on the combined hamartoma complications treatment. However, a number of authors reported cases of pars plana vitrectomy aimed at relieving vitreoretinal traction (epiretinal fibrosis removal) and improving visual acuity to $60 \%[9,10]$. Extravasation may be reduced by intravitreal injection of angiogenesis inhibitor or retinal laser photocoagulation $[11,12]$. The aim of our study was to prove the effectiveness of staged treatment in patients with combined hamartoma of the retina and RPE.

\section{Clinical case}

The female patient, aged 38, complaining of decreased visual acuity in her left eye during the last six months, was admitted to the Scientific Research Center for Ophthalmology of Pirogov Russian National Medical Research University in September 2019. Facts from medical history: in January 2019 the patient seeked medical assistance from ophthalmologist at her place of residence because of the complaints described above; she was diagnosed with thrombosis of superior-temporal branch of the central retinal vein OS and received conservative management; no response to treatment was observed. The systemic disease was ruled out.

On admission, the patient underwent complex assessment by standard methods, such as visometry aimed at determining the best corrected visual acuity (BCVA), indirect ophthalmoscopy using the MaxField non-contact lens (Ocularlnc.; USA), and specific examination methods, such as OCT imaging using the Spectralis HRA+OCT, Module OCT2 platform with a scanning speed of 85,000 Hz (Heidelberg Engineering Inc.; Germany).

At initial examination of the patient's left eye, the BCVA was 0.6. Biomicroscopy demonstrated no pathological changes in the anterior segment. Partial hemophthalmos was identified. Ophthalmoscopy revealed pale-pink optic disk with sharp margins, cellophane macular reflex. Retinal vasculature: superior temporal arcade - arteries with narrowed lumen, veins greatly dilated and tortuous, artery to vein (AN) ratio 1/3; inferior temporal arcade - uniform meshwork of blood vessels; no changes in vessel calibre, $A N$ ratio $2 / 3$. The protruding grey lesion with multiple sites of vitreoretinal traction was identified in the area of the central retinal vein superior temporal branch, the lesion margins were undistinguishable. No peripheral retinal changes were detected. Disorganization of the inner retinal layers (maxi peaks) in the protruding lesion area was observed on spectral-domain OCT scans (Fig. 1A, B). Epiretinal fibrosis was identified on the surface of macular area (Fig. 2).

The patient was diagnosed with combined hamartoma of the retina and RPE complicated by epiretinal fibrosis and partial hemophthalmos in her left eye based on the clinical and instrumental assessment results.

Staged treatment was recommended:

stage 1 - laser photocoagulation aimed at reducing extravasation;

stage 2 - intravitreal administration of angiogenesis inhibitor aimed at reducing vascular permeability in the areas that cannot be subjected to laser photocoagulation, as well as at reducing the risk of intra- and postoperative vitreous haemorrhage;

stage 3 - microinvasive subtotal vitrectomy + schvartectomy + endolaser photocoagulation aimed at restoring of clarity to the ocular media and traction relieving.

Laser photocoagulation (first stage of treatment) was performed using the VISULAS Trion laser workstation (532, 561, $659 \mathrm{~nm}$ ) (Carl Zeiss; Germany). The following energy parameters were used: power was $80 \mathrm{~mW}$, exposure time was $0.1 \mathrm{~s}$, and wavelength was $532 \mathrm{~nm}$. Paravasal irradiation was applied to restricted protruding lesion. One month after laser photocoagulation the BCVA was 0.6. Biomicroscopy detected no pathological changes in the anterior segment. Partial hemophthalmos was identified. Ophthalmoscopy revealed pale-pink optic disk with sharp margins, cellophane macular reflex. Retinal vasculature: superior temporal arcade - arteries with narrowed lumen, veins greatly dilated and tortuous, AN

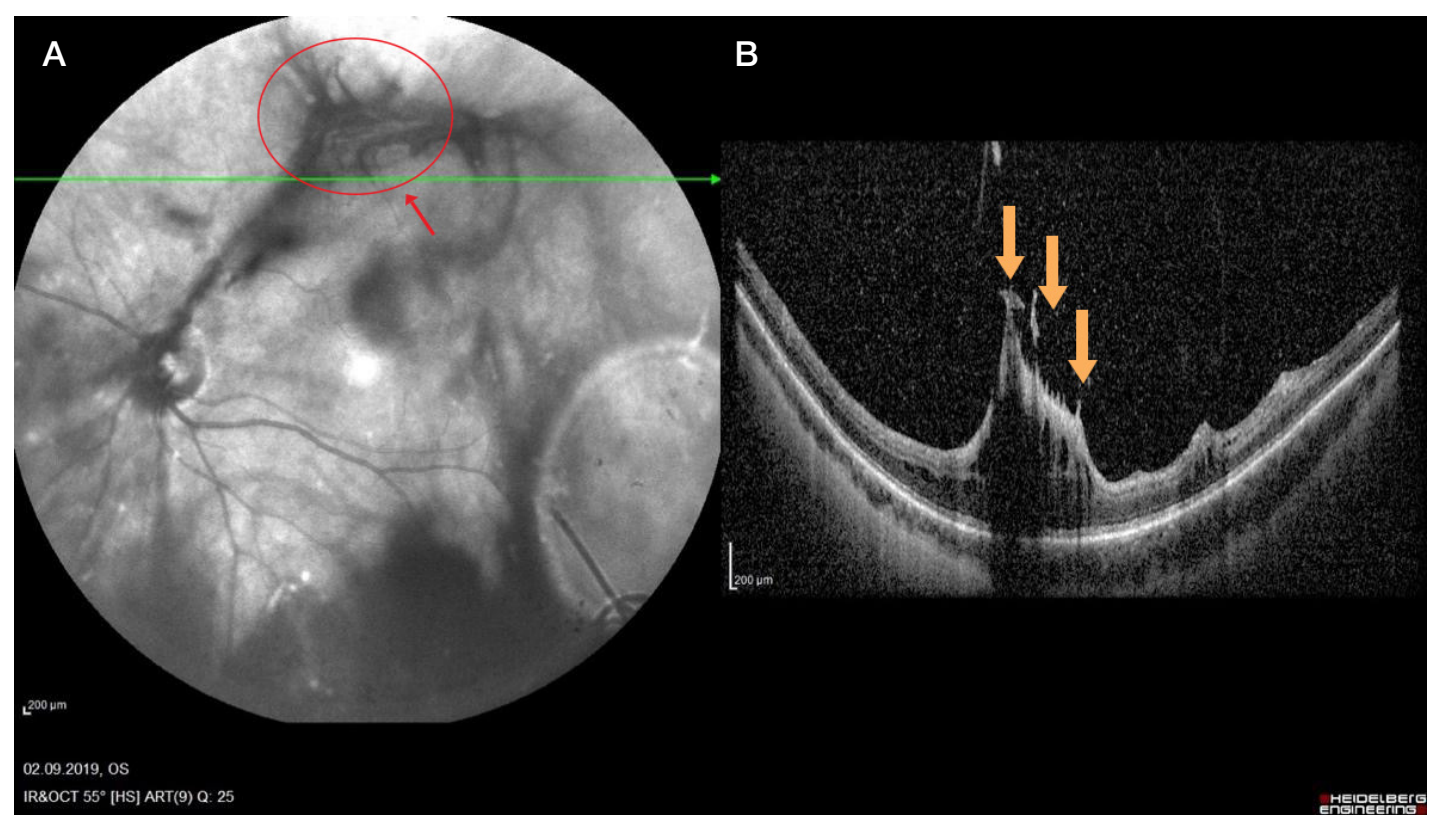

Fig. 1. A. IR reflectance image of fundus: protruding grey lesion with multiple sites of vitreoretinal traction in the area of the central retinal vein superior temporal branch. Partial hemophthalmos. B. OCT scan of retina: disorganization of the inner retinal layers in the protruding lesion area (maxi peaks, yellow arrow) 


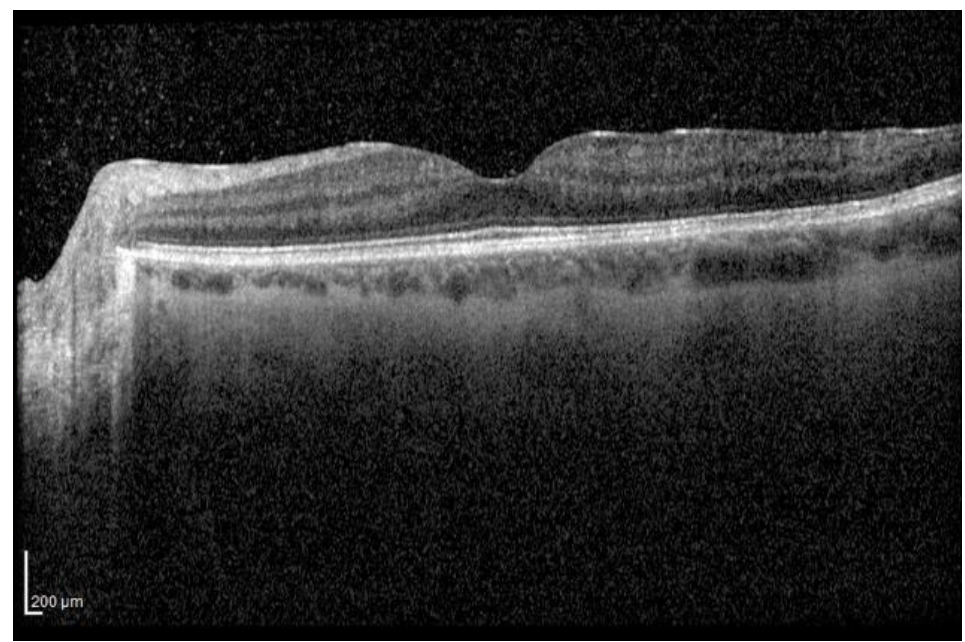

Fig. 2. OCT scan of retina: hyperreflective band in the central area of retinal surface, which is tightly attached to the internal limiting membrane, normal macular profile

ratio 1/3; inferior temporal arcade - uniform meshwork of blood vessels; no changes in vessel calibre, AN ratio 2/3. The protruding grey lesion with multiple sites of vitreoretinal traction was identified in the area of the central retinal vein superior temporal branch, the lesion margins were undistinguishable. Pigmented coagula were visualized in the paravasal area, and the focal area was surrounded by pigmented coagula. OCT revealed no signs of clinical worsening.

One month after laser photocoagulation, during the second stage, the patient's left eye received the intravitreal injection of angiogenesis inhibitor (Aflibercept, $0.1 \mathrm{mg} / 0.04 \mathrm{~mL}$ ). During the check-up performed two weeks later the BCVA was 0.7 . Biomicroscopy demonstrated no pathological changes in the anterior segment. Partial regression of hemophthalmos was detected. Ophthalmoscopy revealed no clinical worsening. No changes were observed on OCT scan.

Three weeks after the intravitreal injection of angiogenesis inhibitor, during the third stage, the patient underwent microinvasive subtotal vitrectomy + schvartectomy + endolaser photocoagulation. One week after surgery the BCVA became 1.0. Biomicroscopy demonstrated no pathological changes in the anterior segment. Avitria was detected. Ophthalmoscopy revealed pale-pink optic disk with sharp margins. Persisting cellophane macular reflex was observed. Retinal vasculature: superior temporal arcade — restored uniformity of blood vessels meshwork, AN ratio $2 / 3$, pigmented coagula visualized in the paravasal area; inferior temporal arcade - uniform meshwork of blood vessels; no changes in vessel calibre, AN ratio 2/3. The vitreoretinal traction along the superior temporal branch of central retinal vein was relieved, the shrunk protruding lesion (optic disk $d=0.5$ ) was surrounded by pigmented coagula (Fig. 3A). Fig. 3B presents the OCT scan.

During the check-up performed three months later no clinical worsening was detected.

\section{Discussion}

To date, there is no generally accepted approach to management of patients with combined hamartoma of the retina and RPE. Literature analysis shows that the disorder may remain asymptomatic for a long period of time, and that the loss of visual function results from complications.

Several treatment options for the disorder and its complications are reported in literature: the effectiveness of radiation therapy in combined hamartoma of the retina and RPE has not yet been proven since the tumor is benign and not radiosensitive [13]; photodynamic therapy, focal laser photocoagulation and intravitreal angiogenesis inhibitor injections are widely

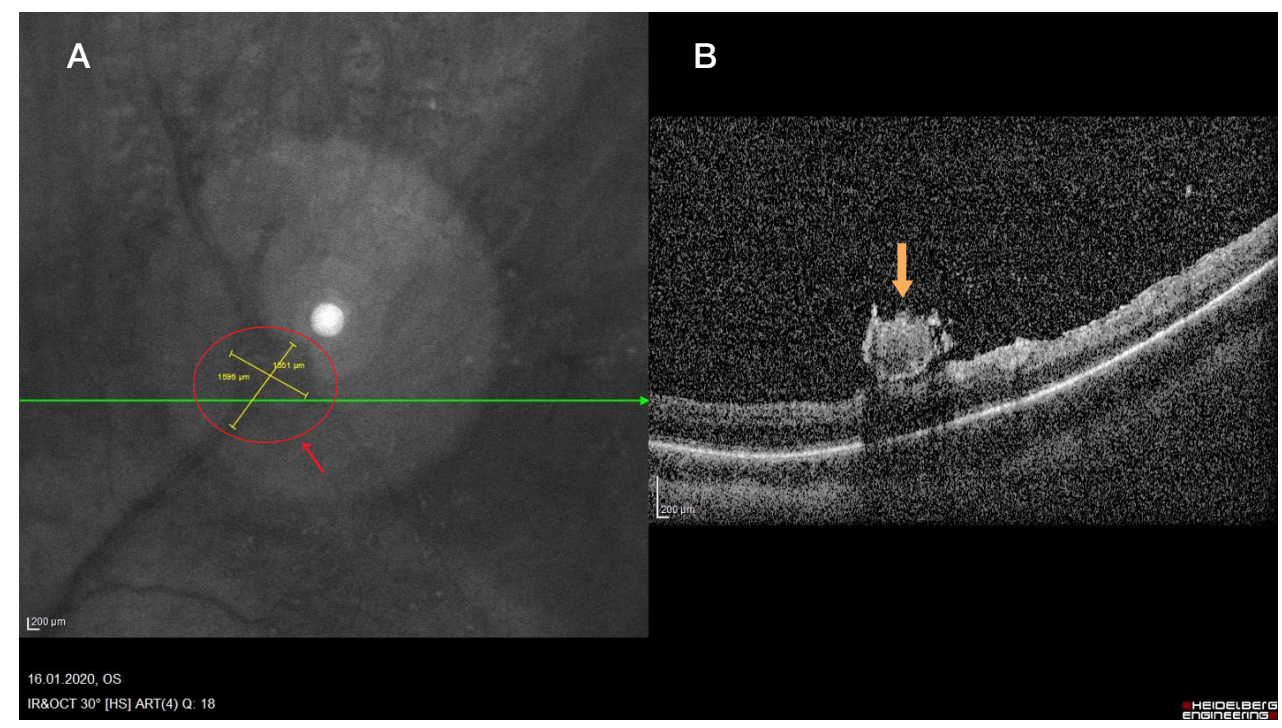

Fig. 3. A. IR reflectance image of fundus a week after the subtotal vitrectomy: restored blood vessels calibre in the superior temporal branch, relieved vitreoretinal traction, shrunk protruding lesion (optic disk $d=0.5$; red arrow) B. OCT scan of retina: single protruding lesion on the retinal surface (yellow arrow) with no vitreoretinal traction, restored anatomic structure of retinal layers 
used in patients with choroidal neovascularization [11, 14]. Angiogenesis inhibitors are also used to reduce the vascular permeability and decrease the risk of vitreous haemorrhage [14]. Subtotal vitrectomy with internal limiting membrane (ILM) and epiretinal membrane (ERM) peeling remains the gold standard for treatment of patients with epiretinal fibrosis. However, this method has a number of limitations: first, the ILM peeling results in damage to Muller glial cells, leading to biomechanical dysfunction of the retina and incomplete recovery of visual function during the postoperative period [15-17]; second, the technical complexity of ILM peeling may result in complications, such as retina injured with instruments for endovitreal intervention, intraretinal hemorrhages in the areas of ILM gripping, high risk of intra- and postoperative vitreous haemorrhage; third, the visual function improvement during the postoperative period correlates with the degree of the retinal layers disorganization [18].

Unlike the international experience, in this study we used staged approach to improve the clinical and functional treatment outcome in patient with combined hamartoma of the retina and RPE, which included paravasal retinal photocoagulation aimed at reducing extravasation at the first stage, intravitreal angiogenesis inhibitor injection aimed at reducing the vascular permeability and the risk of intra- and postoperative haemorrhage at the second stage, and subtotal vitrectomy aimed at restoring of clarity to the ocular media and traction relieving in the area of lesion at the third stage.

Our proposed staged approach to treatment of combined hamartoma of the retina and RPE complicated by partial hemophthalmos and epiretinal fibrosis made it possible to achieve good clinical and functional results: improved BCVA, restored clarity to the ocular media, relieved traction and decreased risk of eventual vitreous haemorrhage.

\section{CONCLUSION}

Personalized staged approach to treatment of combined hamartoma of the retina and retinal pigment epithelium based on the use of advanced diagnosis and treatment methods allowed us to achieve good functional results in the long-term follow-up.

\section{References}

1. Gass JDM. An unusual hamartoma of the pigment epithelium and retina simulating choroidal melanoma and retinoblastoma. Trans Am Ophthalmol Soc. 1973; 71: 171-83.

2. Gupta R, Fung AT, Lupidi M, et al. Peripapillary Versus Macular Combined Hamartoma of the Retina and Retinal Pigment Epithelium: Imaging Characteristics. Am J Ophthalmol. 2019; 200: 263-9.

3. Fonseca RA, Dantas MA, Kaga T, et al. Combined hamartoma of the retina and retinal pigment epithelium associated with juvenile nasopharyngeal angiofibroma. Am J Ophthalmol. 2001; 132 (1): 131-32.

4. Kojen SI, Kvintel G. Flyuorescentnaja angiografija v diagnostike patologii glaznogo dna. M.: Rejtar, 2005; 311 s. Russian.

5. Shields CL, Mashayekhi A, Dai VV, et al. Optical Coherence Tomographic Findings of Combined Hamartoma of the Retina and Retinal Pigment Epithelium in 11 Patients. Arch Ophthalmol. 2005; 123 (12): 1746-50.

6. Arepalli S, Pellegrini M, Ferenczy SR, et al. Combined hamartoma of the retina and retinal pigment epithelium: findings on enhanced depth imaging optical coherence tomography in eight eyes. Retina. 2014; 34 (11): 2202-7.

7. Schachat AP, Shields JA, Fine SL, et al. Combined hamartomas of the retina and retinal pigment epithelium. Ophthalmology. 1984; 91 (12): 1609-15.

8. Kumar V, Chawla R, Tripathy K. Omega Sign: A Distinct Optical Coherence Tomography Finding in Macular Combined Hamartoma of Retina and Retinal Pigment Epithelium. Ophthalmic Surg Lasers Imaging Retina. 2017; 48 (2): 122-5.

9. Cohn AD, Quiram PA, Drenser KA, et al. Surgical outcomes of epiretinal membranes associated with combined hamartoma of the retina and retinal pigment epithelium. Retina. 2009; 29: 825-30.
10. Zhang $X$, Dong $F$, Dai $R$, et al. Surgical management of epiretinal membrane in combined hamartomas of the retina and retinal pigment epithelium. Retina. 2010; 30: 305-09.

11. Nam DH, Shin KH, Lee DY, etal. Vitrectomy, laser photocoagulation, and intravitreal triamcinolone for combined hamartoma of the retina and retinal pigment epithelium. Ophthalmic Surg Lasers Imaging. 2010; 9: 1-4.

12. Xue K, Mellington F, Gout I, et al. Combined hamartoma of the retina and retinal pigment epithelium. BMJ. Case Reports. 2012.

13. Dave T, Dave V, Pappuru R. Combined hamartoma of the retina and retinal pigment epithelium with hypo-autofluorescence and cystic degeneration at the macula. Clin Exp Optom. 2014; 97: 475-6.

14. Cormos D, Ocusan C. Complication of combined retinal and retinal pigment epithelium hamartoma involving optic disc in a child, treated with Avastin - a review of the literature and case presentation. Romanian Journal of Ophtalmology. 2015; 59 (4): 255-62.

15. Tari SR, Vidne-Hay O, Greenstein VC, et al. Functional and structural measurements for the assessment of internal limiting membrane peeling in idiopathic macular pucker. Retina. 2007; 27 (5): $567-72$.

16. Kumagai K, Ogino N, Furukawa M. Retinal thickness after vitrectomy and internal limiting membrane peeling for macular hole and epiretinal membrane. Clin Ophthalmol. 2012; 6: 679-88.

17. Wolf S, Schnurbusch U, Wiedemann P. Peeling of the basal membrane in the human retina: ultrastructural effects. Ophthalmology. 2004; 111: 238-43.

18. Karimov Al, Lyskin PV, Zgoba MI, Makarenko IR. Hirurgicheskoe lechenie makuljarnyh otverstij bez pilinga vnutrennej pogranichnoj membrany. Sovremennye tehnologii v oftal'mologii. 2018; 4: 137-9. Russian.

\section{Литература}

1. Gass JDM. An unusual hamartoma of the pigment epithelium and retina simulating choroidal melanoma and retinoblastoma. Trans Am Ophthalmol Soc. 1973; 71: 171-83.

2. Gupta R, Fung AT, Lupidi M, et al. Peripapillary Versus Macular Combined Hamartoma of the Retina and Retinal Pigment Epithelium: Imaging Characteristics. Am J Ophthalmol. 2019; 200: 263-9.

3. Fonseca RA, Dantas MA, Kaga T, et al. Combined hamartoma of the retina and retinal pigment epithelium associated with juvenile

nasopharyngeal angiofibroma. Am J Ophthalmol. 2001; 132 (1): 131-32.

4. Коэн С. И., Квинтель Г. Флюоресцентная ангиография в диагностике патологии глазного дна. М.: Рейтар, 2005; 311 с.

5. Shields CL, Mashayekhi A, Dai WV, et al. Optical Coherence Tomographic Findings of Combined Hamartoma of the Retina and Retinal Pigment Epithelium in 11 Patients. Arch Ophthalmol. 2005; 123 (12): 1746-50.

6. Arepalli S, Pellegrini M, Ferenczy SR, et al. Combined hamartoma 
of the retina and retinal pigment epithelium: findings on enhanced depth imaging optical coherence tomography in eight eyes. Retina. 2014; 34 (11): 2202-7.

7. Schachat AP, Shields JA, Fine SL, et al. Combined hamartomas of the retina and retinal pigment epithelium. Ophthalmology. 1984 91 (12): 1609-15.

8. Kumar V, Chawla R, Tripathy K. Omega Sign: A Distinct Optical Coherence Tomography Finding in Macular Combined Hamartoma of Retina and Retinal Pigment Epithelium. Ophthalmic Surg Lasers Imaging Retina. 2017; 48 (2): 122-5.

9. Cohn AD, Quiram PA, Drenser KA, et al. Surgical outcomes of epiretinal membranes associated with combined hamartoma of the retina and retinal pigment epithelium. Retina. 2009; 29: 825-30.

10. Zhang $X$, Dong F, Dai R, et al. Surgical management of epiretinal membrane in combined hamartomas of the retina and retinal pigment epithelium. Retina. 2010; 30: 305-09.

11. NamDH, Shin KH, Lee DY, etal. Vitrectomy, laser photocoagulation, and intravitreal triamcinolone for combined hamartoma of the retina and retinal pigment epithelium. Ophthalmic Surg Lasers Imaging. 2010; 9: 1-4.

12. Xue K, Mellington F, Gout I, et al. Combined hamartoma of the retina and retinal pigment epithelium. BMJ. Case Reports. 2012.
13. Dave T, Dave V, Pappuru R. Combined hamartoma of the retina and retinal pigment epithelium with hypo-autofluorescence and cystic degeneration at the macula. Clin Exp Optom. 2014; 97: 475-6.

14. Cormos D, Ocusan C. Complication of combined retinal and retinal pigment epithelium hamartoma involving optic disc in a child, treated with Avastin - a review of the literature and case presentation. Romanian Journal of Ophtalmology. 2015; 59 (4): 255-62.

15. Tari SR, Vidne-Hay O, Greenstein VC, et al. Functional and structural measurements for the assessment of internal limiting membrane peeling in idiopathic macular pucker. Retina. 2007; 27 (5): 567-72

16. Kumagai K, Ogino N, Furukawa M. Retinal thickness after vitrectomy and internal limiting membrane peeling for macular hole and epiretinal membrane. Clin Ophthalmol. 2012; 6: 679-88.

17. Wolf S, Schnurbusch U, Wiedemann P. Peeling of the basal membrane in the human retina: ultrastructural effects. Ophthalmology. 2004; 111: 238-43.

18. Каримов А. И., Лыскин П. В., Згоба М. И., Макаренко И. Р. Хирургическое лечение макулярных отверстий без пилинга внутренней пограничной мембраны. Современные технологии в офтальмологии. 2018; 4: 137-9. 